\title{
Advanced Oxidation of Olive Mill Wastewater OMW by an Oxidative Free- Radical Process Induced With Zero Valent Iron
}

\author{
Jamil Rima $^{1}$, Kamil Rahme ${ }^{2} \&$ Karrine Assaker ${ }^{1}$ \\ ${ }^{1}$ Chemistry of environmental engineering and biology Fanar, Lebanese University Faculty of sciences II, Fanar, \\ Lebanon \\ ${ }^{2}$ Faculty of Natural and Applied Sciences, Notre Dame University (NDU) Louaize, Zouk Mosbeh, Lebanon \\ Correspondence: Jamil Rima, Chemistry of environmental engineering and biology Fanar, Lebanese University \\ Faculty of sciences II, Fanar, Lebanon. Tel: 961-3-321-833. E-mail: jamil.rima1@gmail.com
}

Received: June 24, 2014 Accepted: August 4, 2014 Online Published: August 8, 2014

doi:10.5539/jfr.v3n6p70 URL: http://dx.doi.org/10.5539/jfr.v3n6p70

\begin{abstract}
The degradation of olive mill wastewater (OMW) with hydroxyl radicals generated from zero-valent iron and hydrogen peroxide has been investigated by means of chemical oxygen demand (COD) and phenolic compounds analyses. The mechanism uses zero-valent iron activated by oxygen at room temperature to generate Hydroxyl-free radicals that subsequently oxidize organic constituents and clean wastewater. The effects of the iron mass, the $\mathrm{pH}$ and the organic matter concentration have been studied. Our experimental results demonstrate that the continuous presence of oxygen and iron in an acidic solution with a $\mathrm{pH} 2-4$ allows the generation of maximum hydroxyl free radicals. The lack of oxygen prevents oxidative reaction, and then the generation of free radicals cannot occur. Coloration of OMW disappeared and phenolic compound decreased after 40 minutes of reaction time. The results show that $\mathrm{Fe}^{0} / \mathrm{H}^{+}$/air or oxygen, could be considered as an effective alternative solution for the treatment of OMW.
\end{abstract}

Keywords: radical process, zero-valent iron, degradation, olive mill wastewater; TOC mineralization; COD reduction

\section{Introduction}

The extraction of oil from olive constitutes a large part of food and agricultural processing industries. However, many conventional olive oil production methods create large amounts of waste mixed with other by-products, and unfortunately producers often may not use any method for the purification and further benificial use of those by-products. Therefore, one of the major environmental problems caused by agro-food industry especially in Mediterranean area is the treatment of the olive mill wastewaters OMW (Aragón \& Palancar, 2000). The OMW are extremely rich in organic compounds, and polyphenolic macromolecules that render them harmful for the environment and highly toxic (Chatzisymeon, 2009a; Chatzisymeon, 2009b; Chatzisymeon, 2009c). Consequently, a large volumes production of OMW constitute a serious environmental problem, and pronounced studies to overcome these issue are of high importance for the environment (Skerrat, 1999; Zorpas, 2011). Analysis of the contents in the OMW has shown that various compounds such as organic acids, polysaccharides, tannins, polyphenols, lipids, polyalcohols and pectins are the main by-products of olive oil. The OMW usually presents high concentrations of (COD $\sim 220 \mathrm{~g} \mathrm{~L}^{-1}$ ) in the organic fraction, and other mineral compounds making them difficult to treat and highly polluting fluids (Borja, 1997; Niaounakis \& Halvadakis, 2004; Poerschmann, 2013). It is also well known that an increase in the waste chemicals in rivers decreases the quantity of dissolved oxygen and increases the contents of organic compounds and transition metals (Fadil, 2003; McNamara, 2008)

Conventional wastewater treatment methods, based on chemical, physico-chemical, biological methods, or their combined treatment methods were applied to treat OMW. However, it is well known that these methods present several problems. Moreover, Physico-chemical treatment of OMW by coagulation-flocculation is neither simple nor efficient for the reduction of organic materials in the OMW. Recently, biological treatment methods are used for OMW treatment; these methods are based on aerobic activated sludge and anaerobic digestion and were able to remove partially the organic matters and inorganic nutrients. The use of anaerobic digestions by micro-organisms have been also widely developed (Ubay \& Öztürk, 1997; Fadil, 2003; McNamara, 2008; 
El-Gohary, 2009). However, the polyphenols in the organic fraction of OMW are known to be not easy degradable by natural processes, but studies have also shown that they still contain several natural antioxidants of high value of interest for extraction (Lesage-Meesen, 2001; Fernández-Bolaños, 2006; Bertin, 2011).

Advanced oxidation processes (AOPs) using highly reactive species such as hydroxyl radicals, have been extensively studied to treat efficiently non biodegradable organic species from OMW. Combination of AOPs and conventional aerobic/anaerobic biological processes is the most effective method for OMW treatment (Mekki, 2013; Cesaro, 2013). Generally, research efforts have been mainly directed toward the investigation of the operating conditions of AOPs that affect OMW mineralization and/or detoxification (Chatzisymeon, 2009a; Kiril Mert, 2010), while there are only few studies comparing several processes, including AOPs from the economical point of view (Cañizares, 2009). Beyaz (Beyaz, 2011) and Baldrian (Baldrian, 2006) et al. have used the free radicals generated by the Fenton reaction, which involves the combination of copper, hydrogen peroxide and organic compounds such as pyridine, succinic acid or glucaric acid. However, this processing is limited by the relatively high levels of the COD and the use of a copper catalyst to produce free radicals that may increases the environmental toxicity. In order to degrade phenolic compounds, Noradoun et al. 2003 (Noradoun, 2003) used modified zero valent iron with ethylene diamine tetra acetic acid (EDTA), at ambient conditions. These authors suggested that this process can be initiated by the activation of oxygen.

In the same objective we have previously shown that a different system of oxidation by combination of zero valent iron, bubbling air into the acidic solution can be produced (Rima, 2005). The significant roles of oxygen and $\mathrm{pH}$ on the oxidation process were necessary, to generate hydroxyl free radicals. Free radicals generated were used to mineralize several organic pollutants (Rima, 2006; Rima \& Assaker 2012). However, to the best of our knowledge the treatment of organic materials in OMW, by free radicals generated from zero valent iron is not yet published. Consequently, remediation of water contaminated by toxic organic compounds through their oxidative reaction (mineralization) using rapid and efficient new technology based on the generation of free radicals is shown in this study. Furthermore, contrary to the other methods which are constrained by the concentration of reagents, the novelty of this method in lies on the production of high concentrations of free radicals from commercial zero valent iron (ZVI).

\section{Method}

\subsection{Description of the Studied Wastewater OMW}

The OMW was once collected by a three-phase olive oil mill company, located in south of Lebanon. The effluent was subjected to filtration in order to remove most of its total solids and was then kept at $4{ }^{\circ} \mathrm{C}$ for $24 \mathrm{~h}$, to ensure that its physicochemical characteristics will not be lessened or weathered. The effluent had a strong malodor of degraded olive oil; a dark black brown color, its main properties prior to and after filtration can be significantly affected in some parameters such as TSS (total solid substances) and only slightly in others such as dissolved organic materials. The small change of COD after filtration was due to the dependence of this parameter on TDS (total dissolved substances) which was not removed by filtration.

\subsection{Chemicals and Reagents}

All reagents were of analytical grade. Sodium hydroxide, caffeic acid and hydrochloric acid were purchased from Sigma Chemical Co. (St. Louis, MO, USA). Zero valent iron powder (ZVIP) (325 mesh) was purchased from Merck (Darmstadt, Germany). The ZVIP was washed with $\mathrm{HCl}(0.1 \mathrm{M})$ to remove impurities from the particles surface. All dilutions and glassware rinsing were performed using (Millipore) MilliQ distilled water system adopting filtration by a Millpack 40 cartridge $(0.22 \mu \mathrm{m})$.

\subsection{Reactor Pilot}

A photo of the reactor pilot is presented in Figure 1. 


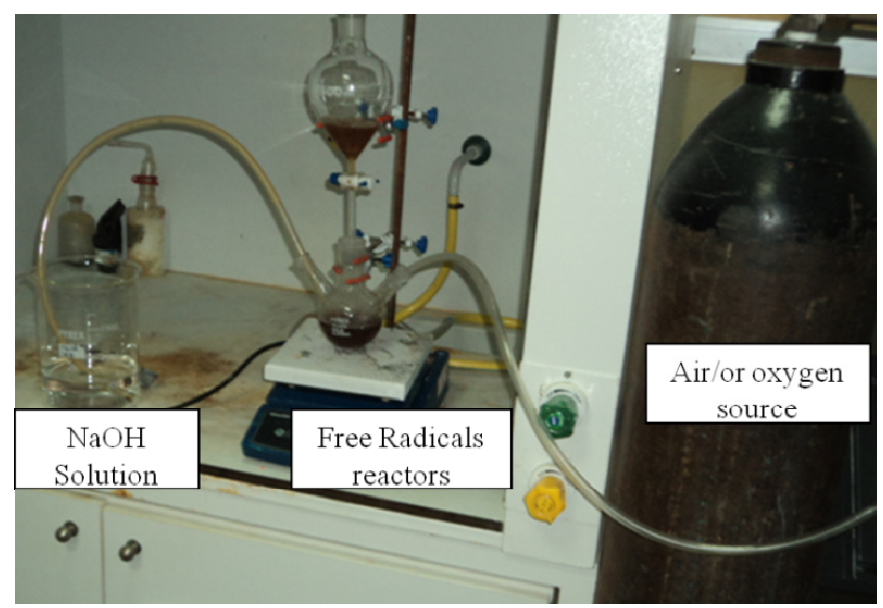

Figure 1. Image illustrates the Oxidation Pilot Reactor used in this study

The reactor is a $250 \mathrm{ml}$ of Pyrex flask equipped with inlets for sampling and oxygen gas bubbling and an outlet for carbon dioxide. A volume of $100 \mathrm{ml}$ of filtered OMW was transferred into the reactor which contains $3 \mathrm{~g}$ of zero-valent iron powder. The $\mathrm{pH}$ of the solution was adjusted when necessary to $\mathrm{pH}=4$ by adding a certain volume of $0.1 \mathrm{M} \mathrm{HCl}$. This $\mathrm{pH}$ value was found to be more favorable for free radicals generation. The mixture was then exposed to bubbling oxygen or air gas into the reactor. The carbon dioxide produced by the reaction was trapped into a sodium hydroxide solution, as shown in Figure $1(\mathrm{NaOH}$ is used to verify the production of $\mathrm{CO}_{2}$ produced by the mineralization of organic contents).

Aliquots $(3 \mathrm{~mL})$ were taken from the reaction solution at regular $10 \mathrm{~min}$ intervals in order to determine the total organic compounds (TOC), the chemical oxygen demand components (COD), as well as the aromatic and total polyphenol compounds content in the reaction mixture. In order to study the effect of the iron mass on the efficiency of the reaction we proceeded as follow:

A volume of $100 \mathrm{~mL}$ of OMW solutions with $\left(\mathrm{COD}=400 \mathrm{mg} \mathrm{L}^{-1}\right)$, were transferred successively in the reactor and adjusted to $\mathrm{pH}=4$ followed by addition of ZVIP 5; 10 and $30 \mathrm{~g} \mathrm{~L}^{-1}$ respectively. Oxygen gas or air was bubbled into the mixture. Aliquots of the solution $(3 \mathrm{~mL})$ were withdrawn each $10 \mathrm{~min}$ for subsequent analysis. In this experiment we have selected randomly the OMW concentration because our objective was to verify that the degradation of organic compounds leads to the formation of carbon dioxide. The concentration of COD used here is $400 \mathrm{mg} \mathrm{L}^{-1}$, and it was obtained by diluting the mother solution $\left(40 \mathrm{~g} \mathrm{~L}^{-1}\right) 100$ times.

\subsection{Physiochemical Analysis of the OMW and COD Measurements}

All tests were conducted according to standard methods for examination of water and wastewater (American Water Works Association (AWWA 2000)). The COD was measured using method $5220 \mathrm{C}$ (closed reflux, titrimetric method), the total nitrogen was assessed by macro-Kjeldahl method (method 4500-Norg B), and the vanadomolybdophosphoric acid colorimetric method 4500-PC was used for phosphorus measurements. The concentration of the fat, oil, and grease (FOG) was determined by $5520 \mathrm{~B}$ method (partition-gravimetric method). The $\mathrm{pH}$ was measured with a Mettler Toledo $\mathrm{pH}-$ meter. Table 1 summarizes the physiochemical properties of the OMW solution measured obtained here. 
Table 1. Levels of the physiochemical parameters of wastewater OMW samples

\begin{tabular}{ccc}
\hline \multirow{2}{*}{ Parameters } & \multicolumn{2}{c}{ Mean value } \\
\cline { 2 - 3 } & Before filtration & After filtration \\
\hline $\mathrm{BOD}_{5}\left(\mathrm{~g} \mathrm{~L}^{-1}\right)$ & 30.6 & 25 \\
$\mathrm{TDS}\left(\mathrm{g} \mathrm{L}^{-1}\right)$ & 27.3 & 23.4 \\
$\mathrm{PH}$ & 4.6 & 4.4 \\
Total Kjeldahl nitrogen, $\mathrm{mg} \mathrm{L}^{-1}$ as N & 532 & 485 \\
$\mathrm{TSS},\left(\mathrm{g} \mathrm{L}^{-1}\right)$ & 50.3 & 0.6 \\
Oil $\left(\mathrm{g} \mathrm{L}^{-1}\right)$ & 6.5 & 0.01 \\
Total Organic Carbon $\left(\mathrm{g} \mathrm{L}^{-1}\right)$ & 14.5 & 12.4 \\
COD $\left(\mathrm{g} \mathrm{L}^{-1}\right)$ & 47 & 40 \\
Total Phosphorus $\left(\mathrm{g} \mathrm{L}^{-1}\right)$ & 0.59 & 0.50 \\
Total phenols $\left(\mathrm{g} \mathrm{L}^{-1}\right)$ & 8.1 & 3.5 \\
Sugar $\left(\mathrm{g} \mathrm{L}^{-1}\right)$ & 4.3 & 3.2 \\
Proteins $\left(\mathrm{gL}^{-1}\right)$ & 1.8 & 1.3 \\
\hline
\end{tabular}

\subsection{Aromatic and Phenolic Compounds Determination}

Previously, several papers have addressed the chemical degradation in wastewater OMW either by direct UV photolysis or by AOP (Fajerwerg, 1997; Catrinescu, 2003). The main reactions are aromatic ring oxidation, ring cleavage and carboxylic acid formation. The decolorization of OMW corresponds to depolymerization of high molecular mass aromatics combined with mineralization of a wide range of mono-aromatic. The aromatic compounds were determined globally by measuring the absorbance of the samples at the maximum wavelength $\lambda_{\max }=254 \mathrm{~nm}\left(\mathrm{~A}_{\max }\right.$ of these organic compounds) and are expressed as $\mathrm{mg}$ of phenol per liter (Beltran de Heredia 2005). The total phenolic contents of wastewater OMW were determined according to the method described by Malik and Singh (Malik \& Singh, 1980). Aliquots of the OMW solution were taken in a $10 \mathrm{ml}$ glass tube and made up to a volume of $3 \mathrm{ml}$ with distilled water. Then $0.5 \mathrm{~mL}$ folin ciocalteau reagent (1:1 with water) and $2 \mathrm{~mL} \mathrm{Na} \mathrm{CO}_{3}(20 \%)$ were added sequentially in each tube. A blue color was developed in each tube because the phenols undergo a complex redox reaction with phosphomolibdic acid in folin ciocalteau reagent in alkaline medium which resulted in a blue colored complex, molybdenum blue. The test solutions were warmed for 1 minute, then cooled and absorbance was measured at $650 \mathrm{~nm}$ against the reagent used as a blank. A standard calibration curve was generated at $650 \mathrm{~nm}$ using known concentrations of catechol. The concentrations of phenols in the test samples were calculated from the calibration curve and expressed as mg catechol equivalent of phenol per gram of sample. Total organic carbon (TOC) contents in Pilot Reactor were measured before and after reaction using a Shimadzu TOC Analyzer model 5050A (Japan) where water was used as blank controls. The carbon dioxide is detected by the non-dispersive infrared gas analyzer detector (NDIR).

\subsection{Demonstration of Free Radical Generation From ZVI}

Deoxyribose stock solution was prepared at $200 \mathrm{mg} \mathrm{L}^{-1}(1.5 \mathrm{mM})$. The final concentrations of deoxyribose $(0.6$ $\mathrm{mM}$ ) were prepared by performing appropriate dilution. The ZVI was added to the vial containing $100 \mathrm{~mL}$ of deoxyribose solution followed by adjusting the $\mathrm{pH}$ to 4 . The vial was sealed with a butyl rubber stopper, and shaken continuously for the duration of the experiment $(3 \mathrm{~min})$. For the analysis, an aliquot of $3 \mathrm{~mL}$ of the sample solution was added to $3 \mathrm{~mL}$ of TBA (thiobarbutiric acid) in $15 \%$ acetic acid ( $1 \%$ of TBA, w/v). The mixture was heated in a water bath maintained at $100{ }^{\circ} \mathrm{C}$ for $15 \mathrm{~min}$. afterward the mixture was cooled and the absorption spectrum of the mixture was recorded.

\section{Results}

\subsection{Degradation of Organic Constituents of OMW}

Through the central neck $100 \mathrm{~mL}$ solution diluted four times from the initial OMW (COD $=400 \mathrm{mg} \mathrm{L}^{-1}$ ) were transferred into the reactor which contains $4 \mathrm{~g}$ of zero valent iron (325 mesh). While bubling the solution with oxygen or air stream routed through the left neck (Figure 1), the $\mathrm{pH}$ was verified. The stream of gas (oxygen/air) can play the role of a stirrer in the mixture of the reaction. The right neck was used as output to route the $\mathrm{CO}_{2}$ 
toward the alkaline solution.The oxidation process of organic constituents or its mineralization (production of $\mathrm{CO}_{2}$ ) was illustrated by trapping the $\mathrm{CO}_{2}$ produced in a $\mathrm{NaOH}$ solution. The degradation of organic constituents was deducted from the measurements of COD, TOC, aromatic and phenolic levels at different time intervals during the oxidation process in the pilot reactor that was subjected to free radical generation using ZVI.

\subsubsection{Trapping of Carbon Dioxide by Sodium Hydroxide Solution}

Carbon dioxide has been monitored during the oxidation reaction by its effect on $100 \mathrm{~mL}$ of $0.25 \mathrm{mM}$ sodium hydroxide solution. The $\mathrm{pH}$ of sodium hydroxide was found to decrease from 10.4 to 7.3 after about fifty minutes. This decrease in $\mathrm{pH}$ justifies the mineralization of the organic constituents in the OMW through the production of $\mathrm{CO}_{2}$. A volumetric analysis was used to assay the carbon dioxide generated during the oxidation reaction. The carbon dioxide formed is driven by the stream of air free of $\mathrm{CO}_{2}$ to the solution of sodium hydroxide. A titration of sodium hydroxide solution with N/10 hydrochloric acid was performed.

Let $\mathrm{V}_{\mathrm{a}}(\mathrm{mL})$ volume of acid solution required for the neutralization of basic solution before the reaction of oxidation, and $\mathrm{V}_{\mathrm{b}}$ is the volume of acid required to neutralize the same volume of the sodium hydroxide in which the reaction of oxidation was carried out. The calculation of carbon dioxide was performed in the following way:

$\left(\mathrm{V}_{\mathrm{a}}-\mathrm{V}_{\mathrm{b}}\right) / 10 \times 44 \mathrm{mg}$

In this case $\left(\mathrm{V}_{\mathrm{a}}-\mathrm{V}_{\mathrm{b}}\right)=3.41 \mathrm{~mL}$ which means that the mass of $\mathrm{CO}_{2}$ generates from the OMW diluted 4 times is $14.93 \mathrm{mg} / 100 \mathrm{~mL}$. This test was performed to show that during the oxidation reaction using zero valent iron $\left(\mathrm{Fe}^{0}\right)$, organic compounds present in the solution are transformed by mineralization into carbon dioxide, which is absorbed by the solution of sodium hydroxide and thus decreasing its $\mathrm{pH}$ in time that is explicitly justified by $\mathrm{CO}_{2}$ production. We note that in order to check the effect of bubbling air or oxygen on the $\mathrm{pH}$ of trapper solution, we have tested the experiment before adding OMW solution, and no any change in the $\mathrm{pH}$ was detected.

\subsubsection{COD (Chemical Oxygen Demand Constituents)}

Tests were conducted in $100 \mathrm{~mL}$ aliquots of $\mathrm{OMW}$ aqueous solution adjusted to $\mathrm{pH}=4$ by using $0.1 \mathrm{M} \mathrm{HCl}$, and then transferred into the reactor. Each sample contains $4 \mathrm{~g}$ of ZVIP, which was bubbled with oxygen gas. Samples of $3 \mathrm{~mL}$ were withdrawn at $0,10,20,30,40$ and 50 minutes from the OMW wastewater treated for measurement of COD at regular periods time of treatment. The COD measurement was carried out by titrimetric method. The oxidation efficiency of organics was then calculated. Figure 2 shows the evolution of the COD percent versus time of an oxidation reaction in the OMW solution with initial concentration $250 \mathrm{mg} \mathrm{L}^{-1}$. It can be clearly seen from Figure that after 50 min of treatment the decreasing of COD reaches $99 \%$.

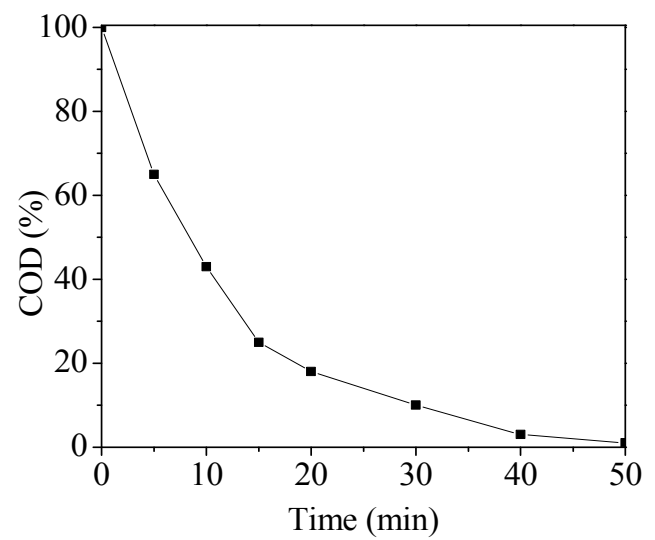

Figure 2. Evolution of COD \% versus time of oxidation reaction in the OMW solution $\left(250 \mathrm{mg} \mathrm{L}^{-1}\right) \mathrm{pH}=4$, $\left[\mathrm{Fe}^{0}\right]=4 \mathrm{gL}^{-1}$, bubbling with air

\subsubsection{TOC (Total Organic Compounds) Constituents}

The mass of carbon dioxide released during the oxidation reaction is indicative of the mass of organic carbon initially present in the sample. The variation of the total organic carbon (TOC) levels was measured in OMW 
solutions in order to track the disappearance of the organic compounds. The carbon dioxide generated by the reaction was detected by the NDIR detector of the TOC Analyzer, which is indicative of the conversion of phenolics, aromatic hydrocarbons, etc. at the end of the reaction. The TOC dissipation and carbon dioxide emitted during the reaction is illustrated in Figure 3.

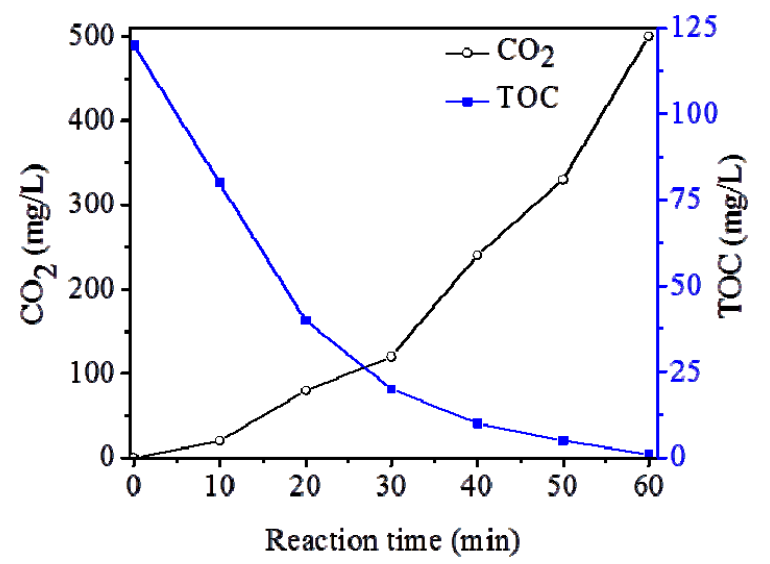

Figure 3. Evolution of TOC and carbon dioxide formation $\left(\mathrm{CO}_{2}\right)$ in OMW solution $\left(400 \mathrm{mg} \mathrm{L}^{-1}\right)$ during the time of the oxidation reaction $. \mathrm{pH}=4,\left[\mathrm{Fe}^{0}\right]=4 \mathrm{~g} \mathrm{~L}^{-1}$

It is obvious from the plot that our results display an increase in the production of carbon dioxide as TOC decreases, reflecting on the rate of the organic degradation. Furthermore, our results portrayed (Figure 3 ) that after 50 min, more than $98 \%$ of organics were disappeared (degraded).

\subsubsection{Total Aromatic Compound Constituents}

This experiment was carried out to see the evolution of aromatic compounds such as polyphenol well present in OMW and color after 40 minutes reaction time at an initial $\mathrm{pH}$ of 4 and initial COD of $400 \mathrm{mg} \mathrm{L}^{-1}$

(González-Rodríguez 2002). UV spectrophotometry was used to monitor the degradation of the aromatic compounds (phenolics or polyphenolic) that absorb between $200 \mathrm{~nm}$ and $600 \mathrm{~nm}$ (Figure 4).

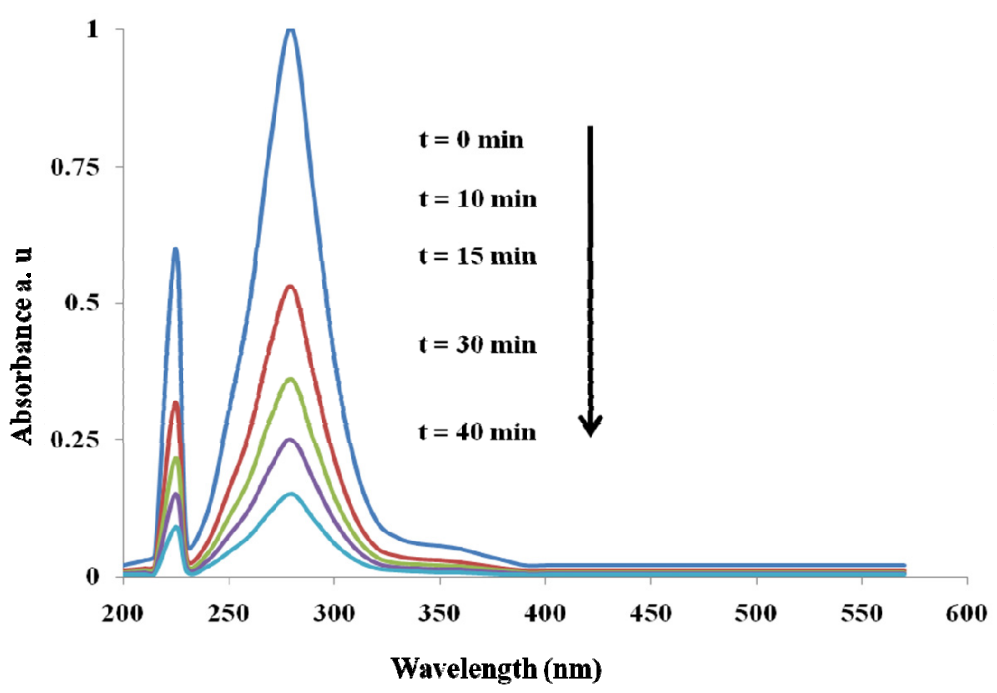

Figure 4. Phenolic chromospheres compounds evolution during the OMW oxidation reaction monitored by $\mathrm{UV}$-visible Absorption (initial $\mathrm{pH}=4,\left[\mathrm{Fe}^{0}\right]=4 \mathrm{~g} \mathrm{~L}^{-1}$, initial $\mathrm{COD}=\left(400 \mathrm{mg} \mathrm{L}^{-1}\right)$

The spectrum of aromatic compounds shows two characteristic absorbance bands at 225 and $280 \mathrm{~nm}$. The 
absorbance at $280 \mathrm{~nm}$ of OMW solutions withdrawn from the reactor subjected to free radical production from zero valent iron at different times was shown to decrease with time as the reaction is proceeding. A fast degradation of phenolic compounds was observed the first 10 minutes of the reaction $(50 \%$ of the amount of COD is already degraded during 10 minutes). The reduction in the optical density with time from $A_{280}=0.99$ to 0.15 in $40 \mathrm{~min}$ was further observed. This gradual reduction of the absorption intensity proves that the deterioration of the polyphenols chromophores groups occurs. It is evident from the variation spectra that after 40 min the spectrum become in the limit of detection, indicating the degradation of more than $90 \%$ of the aromatic constituents of olive mill wastewater.

\subsection{Effect of the Iron Masses on the Efficiency of OMW Pollutant Degradation and Kinetic Study of OMW Degradation}

To study the effect of the iron mass on the speed of the oxidation reaction, we realized experiments with three different weight of iron: $1 \mathrm{~g}, 10 \mathrm{~g}$, and $30 \mathrm{~g}$ respectively. The $\mathrm{pH}$ was adjusted to 4 and a stream of oxygen was routed into the reactor. In each experiment samples of $3 \mathrm{~mL}$ were withdrawn at given intervals of time in order to measure the COD and absorbance. For any particular amount of iron, OMW degradation under oxidation conditions was found to exhibits pseudo first-order decay with a linear dependence of $\operatorname{Ln}\left[\mathrm{A}_{0} / \mathrm{A}\right]$ versus time. Figure 5 shows a linear dependence OMW $\left(400 \mathrm{mg} \mathrm{L}^{-1}\right)$ degradation rate for the amount of iron.

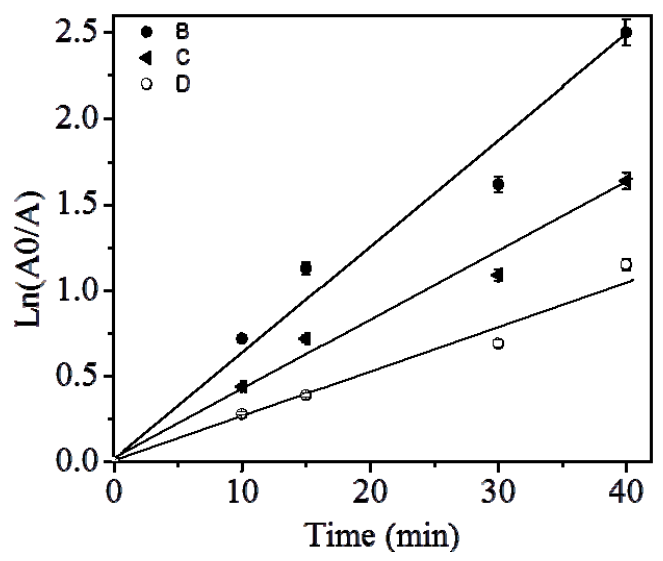

Figure 5. Phenolic Effect of the amount of $\mathrm{Fe}^{0}$ on the OMW degradation rate using $1 \mathrm{~g} \mathrm{~L}^{-1}(\mathrm{D}), 10 \mathrm{~g} \mathrm{~L}^{-1}(\mathrm{C})$, and $30 \mathrm{~g} \mathrm{~L}^{-1}(\mathrm{~B})$ of $\mathrm{Fe}^{0}(325 \mathrm{mesh})$ in OMW solutions $\left[\mathrm{COD}=400 \mathrm{mg} \mathrm{L}^{-1}\right]$ at $\mathrm{pH}=4$

As can be seen in this figure the OMW pollutants disappearance rate is strongly dependent on the initial amount of iron which affects the observed degradation rate $\left(\mathrm{k}_{o b s}\right)$ of OMW, presumably because the reactive $\mathrm{Fe}^{0}$ site increases proportionally with $\mathrm{Fe}^{0}$ concentration. The linear regression of $\mathrm{k}_{o b s}$ versus $\mathrm{Fe}^{0}$ content was

$$
\mathrm{k}_{\text {obs }}=0.001\left[\mathrm{Fe}^{0} \text { content }\left(\mathrm{g} \mathrm{L}^{-1}\right)\right]+0.023
$$

Table 2 summarizes the results obtained for the degradation rates in function of the mass of iron. Half- life time of OMW decreases from $26 \mathrm{~min}$ to $11.5 \mathrm{~min}$ with increasing the amount of iron from 1 to $30 \mathrm{~g} \mathrm{~L}^{-1}$.

Table 2. Kinetics of OMW pollutant degradation $\left(\mathrm{COD}=400 \mathrm{mg} \mathrm{L}^{-1}\right)$ in function of the mass of iron powder

\begin{tabular}{cccc}
\hline Mass of iron (g) & Linear equation & kobs $\left(\mathbf{m i n}^{-\mathbf{1}}\right)$ & $\mathbf{R}^{\mathbf{2}}$ \\
\hline 30 & (B) $\mathrm{Y}=0.058 \mathrm{x}+0.089$ & 0.058 & 0.974 \\
10 & (C) $\mathrm{Y}=0.038 \mathrm{x}+0.040$ & 0.038 & 0.983 \\
1 & (D) $\mathrm{Y}=0.027 \mathrm{x}+0.029$ & 0.027 & 0.987 \\
\hline
\end{tabular}

\subsection{Detection of Free Radicals}

The reaction of deoxyribose and hydroxyl free radical has been extensively discussed in the literature (Gutteridge, 1981; Gutteridge, 1984; Aruoma, 1993). In this reaction, the Hydroxyl radicals attack deoxyribose 
to form products that react with TBA upon heating at low $\mathrm{pH}$ and yield a pink chromogen. Figure 6 , show the mechanism of chromogen formation from the reaction of deoxyribose and hydroxyl free radicals generated from $\mathrm{Fe}^{0}$ powder, followed by the reaction with Thiobarbituric acid (TBA), that lead to Thiobarbituric reactive substances (TBARS), these later are the low molecular weight end products constituted essentially from malondialdehyde that are formed during the reaction.

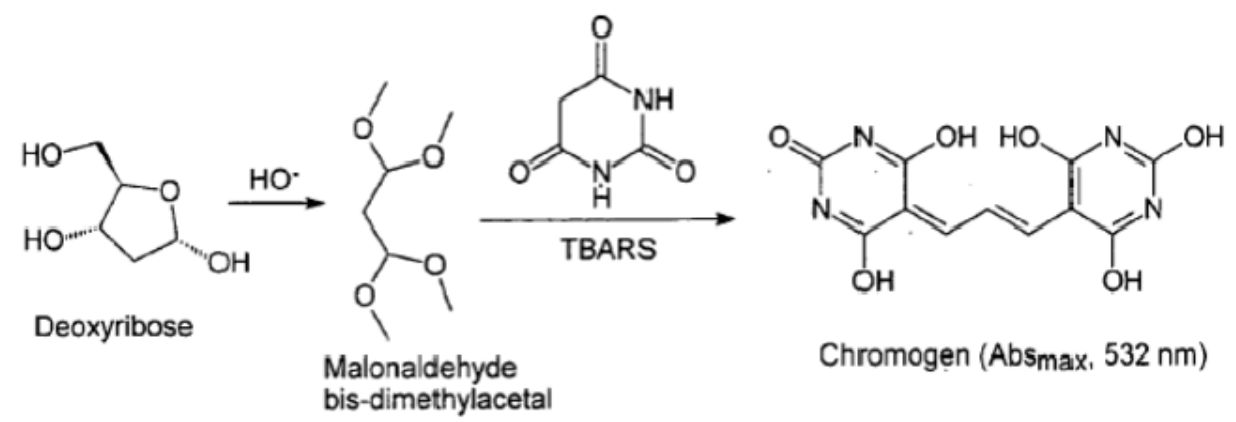

Figure 6. Mechanism of formation of chromogen from the reaction of deoxyribose and hydroxyl free radicals generated from zero-valent iron followed by reaction with thiobarbituric acid (TBA); thiobarbiturate reactive substances (TBARS) are the low molecular weight end products, their main component is malondialdehyde, that are formed during the reaction)

Figure 7 shows the absorption spectrum of chromogen formed, which is identical to the spectrum of malonaldehyde bis-dimethylacetal (MDA)-TBA adduct (i.e., chromogen) obtained by Kosugi et al. (Kosugi 1987) There is one possibility to transform deoxyribose to MDA, which must be derived from a reaction between deoxyribose and hydroxyl free radicals. Hydroxyl free radicals are generated from ZVIP in aqueous buffer solution at $\mathrm{pH}=4$. In this section, we demonstrated that when zerovalent iron powder was mixed in aqueous solutions at $\mathrm{pH}$ less than 6 and under oxygen gas, the free radicals can be generated and indirectly observed by its reaction with TBA and chromogen formation as described previously.

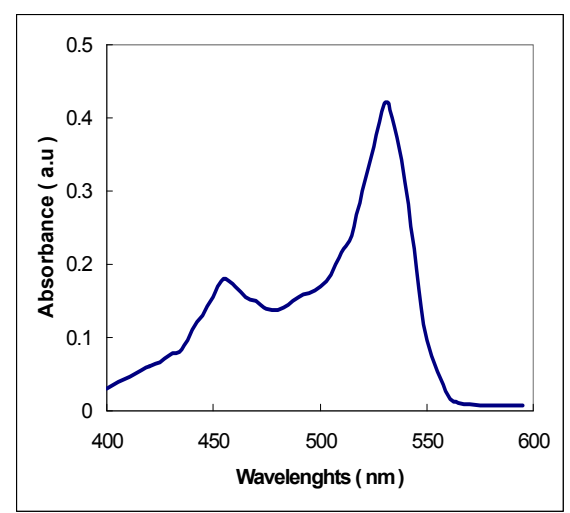

Figure 7. Absorption spectrum of chromogen $\left(\lambda_{\max }=532 \mathrm{~nm}\right)$. An aliquot of $3 \mathrm{~mL}$ of TBA was added into an equal volume reaction mixture of iron and deoxyribose in a solution $\mathrm{pH}=4$, and then was heated at $100{ }^{\circ} \mathrm{C}$ for $15 \mathrm{~min}$

The free radicals generated according to the mentioned conditions (acidic $\mathrm{pH}$, presence of oxygen gas and the use of zero valent iron powder) should be able to mineralize the organic compounds present in the aqueous solution such as OMW organic pollutants

\subsection{Effect of the Presence of Oxygen}

The degradation of OMW pollutants $\left(400 \mathrm{mg} \mathrm{L}^{-1}\right)$ was examined both under deoxygenated by purging nitrogen in the reactor and in the presence of air or $100 \%$ oxygen. Experimental data show slight removal of OMW in a solution at $\mathrm{pH}=4$ and in the absence of oxygen; while $70 \%$ removal was observed after 15 min when the sample 
was bubbled with air or oxygen and when the amount of iron is $3 \mathrm{~g} \mathrm{~L}^{-1}$. Removal was further enhanced when the suspension was bubbled with pure oxygen. The presence of oxygen in the degradation process lead to the hydroxyl free radicals according to our hypothesis proposed in the introduction.

$$
\begin{gathered}
\mathrm{Fe}^{0}+\mathrm{O}_{2 \text { (aq) }}+2 \mathrm{H}^{+} \rightarrow \mathrm{Fe}^{2+}+\mathrm{H}_{2} \mathrm{O}_{2} \rightarrow \mathrm{Fe}^{3+}+\cdot \mathrm{OH}+\mathrm{OH}^{-} \\
\text {Free radicals }+ \text { Organics } \rightarrow \text { Mineralization }
\end{gathered}
$$

However under nitrogen gas the oxidative reaction cannot be observed due to the unfavorable free radical formation.

\subsection{Effect of Initial $\mathrm{pH}$}

In order to observe the effect of $\mathrm{pH}$ on the degradation of $\mathrm{OMW}$, experiments were carried out at different $\mathrm{pH}$ value between 2 and 7. Figure 8 shows the influence of $\mathrm{pH}$ on the organic matter degradation during the reaction oxidation of OMW. The removal of COD decreases with the increase of $\mathrm{pH}$. When tested with $\mathrm{pH}$ less than 4, no significant differences in treatment efficiency are observed. The average of COD removals is about $75 \%$ with 3 $\mathrm{g} \mathrm{L}^{-1}$ of metallic iron, and $78 \mathrm{mg} \mathrm{L}^{-1}$ of initial COD. At $\mathrm{pH} 4.8$ the COD removal is about $23 \%$. Therefore, the optimum $\mathrm{pH}$ level is between 2 and 4 .

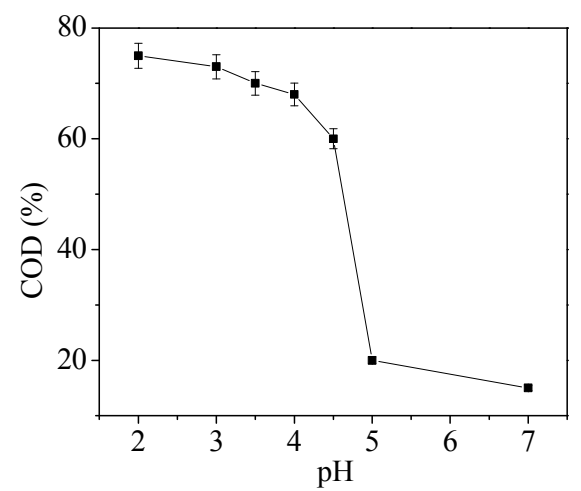

Figure 8. Effect of initial $\mathrm{pH}$ on the COD removal during the OMW oxidation $\left(\left[\mathrm{Fe}^{0}\right]=30 \mathrm{~g} \mathrm{~L}^{-1}\right.$, reaction time: 40 $\min$, initial $\mathrm{COD}=78 \mathrm{mg} \mathrm{L}^{-1}$ )

The oxidation reaction generating free radicals is applied optimally at a $\mathrm{pH}$ between 2.5 and 4 . Indeed below $\mathrm{pH}$ 2.5 three mechanisms will decrease the efficiency of the reaction.

i- Ferrous complex formation,

ii- Inhibition of the reaction of $\mathrm{Fe}^{2+}$ and $\mathrm{H}_{2} \mathrm{O}_{2}$

iii- At low $\mathrm{pH}$ increasing of radicals scavenger phenomena.

Moreover beyond $\mathrm{pH} 5$, the formation of ferric complexes may also inhibit the reaction.

\subsection{Effect of Initial COD Concentration}

The aim of this experiment is to optimize the initial COD concentration and to see the feasibility of the reaction

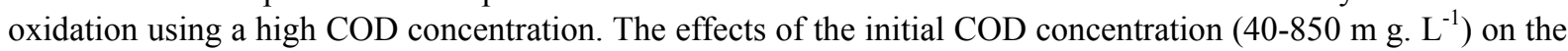
COD removal are shown in Figure 9. 


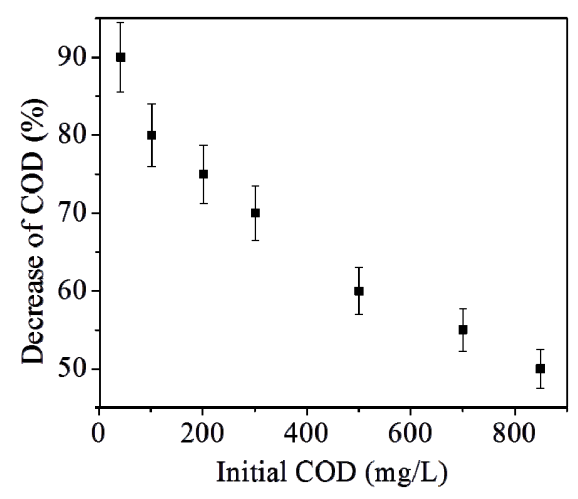

Figure 9. COD decrease (\%) of OMW solution as a function of the initial $\mathrm{COD}\left(\mathrm{mg} \mathrm{L}^{-1}\right) \cdot \mathrm{pH}=4,\left[\mathrm{Fe}^{0}\right]=4 \mathrm{~g} \mathrm{~L}^{-1}$, oxidation reaction time: $15 \mathrm{~min})$. [COD] $=\left(40 \mathrm{mg} \mathrm{L}^{-1}\right.$ to $\left.850 \mathrm{mg} \mathrm{L}^{-1}\right)$

As it can be observed, the rate of COD removal reaches $90 \%$ with the initial COD $=40 \mathrm{mg} \mathrm{L}^{-1}$. The introduction of the oxidation reagents into effluentscontaining relatively low amounts should be an effective method of effluent treatment because of the wide variety of organic molecules that can be converted to $\mathrm{CO}_{2}($ Neyens \& Baeyens, 2003). However, when we increase the COD concentration the COD removal decreases (Figure 9). Indeed, from initial COD $=400 \mathrm{mg} \mathrm{L}^{-1}$, the COD removal was found to be $75 \%$ equivalent to $225 \mathrm{mg} \mathrm{L}^{-1}$, but with initial COD equaled $850 \mathrm{mg} \mathrm{L}^{-1}$, the COD removal was about $50 \%$ equivalent to $382 \mathrm{mg} \mathrm{L}^{-1}$. The time of reaction in this experiment was fixed at 15 minutes.

The above results depend on the formation of hydroxyl radicals and their scavengers. Less scavenging of hydroxyl radicals occurs as initial organic substrate concentration increases (Tekin et al., 2006) without exceeding its optimum group.

\section{Discussion}

We have demonstrated in this study that by using a new system of oxidation which produces hydroxyl radicals through combination of zero valent iron and bubbling air into an acidic solution, we were able to oxidize totally olive mill wastewater OMW pollutant. In fact, the presence of oxygen and a controlled $\mathrm{pH}$ (2.0-4.0) were found to have an important effect on the oxidation process. Organic chemicals such as those present in olive mill wastewater OMW pollutant were found to be mineralized by the Hydroxyl-free radicals during a short time, compared to other technologies of treatment. The COD percent versus time in the OMW solution $\left(250 \mathrm{mg} \mathrm{L}^{-1}\right)$ as well as the TOC were found to decrease by about $99 \%$ after $50 \mathrm{~min}$ of treatment. A fast degradation of phenolic compounds was also detected (50\% of COD in 10 minutes and a total of about $90 \%$ in 40 minutes) by UV-spectroscopy due to the deterioration of the polyphenols chromophores groups. This process provides the advantages of being rapid, facile and environmental friendly way of treating by converting the toxic compounds into carbon dioxide and water. Therefore, advanced oxidation process using zero valent iron (ZVI) under the above mentioned conditions, seems to be a very important system for the generation of high concentrations of highly reactive Hydroxyl free radicals.

\section{Declaration of Interest}

Authors have no conflict of interest, in particular no financial, consulting and personal relationships with other people or organizations that could influence (bias) the author's work.

\section{References}

American Water Works Association and Water Environment Federation. (2000). Standard Methods for the Examination of Water and Wastewater (21ed). USA.

Aragón, J., \& Palancar, M. (2000). Workshop Improlive 2000. S. A. Madrid.

Aruoma, O. (1993). Free Radicals in Tropical Diseases. 281.

Adhoum, N. \& Monser, L. (2004). Decolourization and removal of phenolic compounds from olive mill wastewater by electrocoagulation. Chemical Engineering and Processing, 43(10), 1281-1287. http://dx.doi.org/10.1016/j.cep.2003.12.001

Atanassova, D., Kefalas, P., \& Psillakis, E. (2005). Measuring the antioxidant activity of olive oil mill 
wastewater using chemiluminescence. Environment International, $31(2), \quad 275-280$. http://dx.doi.org/10.1016/j.envint.2004.10.003

Baldrian, P., Zervakis, G. I., Merhautová, V., Ntougias, S., Ehaliotis, C., \& Nerud, F. (2006). The use of hydroxyl-radical-generating systems for the treatment of olive mill wastewaters. Folia Microbiol (Praha), 51(4), 337-341. http://dx.doi.org/10.1007/BF02931827

Bertin, L., Ferri, F., Scoma, A., Marchetti, L., \& Fava, F. (2011). Recovery of high added value natural polyphenols from actual olive mill wastewater through solid phase extraction. Chemical Engineering Journal, 171(3), 1287-1293. http://dx.doi.org/10.1016/j.cej.2011.05.056

Bertín, L., Lampis, S., Todaro, D., Scoma, A., Vallini, G., Marchetti, L., ... Fava, F. (2010). Anaerobic acidogenic digestion of olive mill wastewaters in biofilm reactors packed with ceramic filters or granular activated carbon. Water Research, 44(15), 4537-4549. http://dx.doi.org/10.1016/j.watres.2010.06.025

Beltran, J. de Heredia., Torregrosa, J., Dominguez, J. R., \& Partido, E. (2005). Degradation of wine distillery wastewaters by the combination of aerobic biological treatment with chemical oxidation by Fenton's reagent. Water Science and Technology, 51(1), 167-174.

Beyaz, B., Fungus, Ç., Suyundan, K., \& Giderimi, F. (2011). Dephenolization of Olive Mill Wastewater by Pellets of Some White Rot Fungi. Hacettepe J Biol Chem, 39(4), 379-390.

Borja, R., Alba, J., \& Banks, C. J. (1997). Impact of the main phenolic compounds of olive mill wastewater (OMW) on the kinetics of acetoclastic methanogenesis. Process Biochemistry, 32(2), 121-133. http://dx.doi.org/10.1016/S0032-9592(96)00055-6

Cañizares, P., Paz, R., Sáez, C., \& Rodrigo, M. A. (2009). Costs of the electrochemical oxidation of wastewaters: a comparison with ozonation and Fenton oxidation processes. Journal of Environmental Management, 90(1), 410-420. http://dx.doi.org/10.1016/j.jenvman.2007.10.010

Catrinescu, C., Teodosiu, C., Macoveanu, M., Miehe-Brendle, J., \& Le Dred, R. (2003). Catalytic wet peroxide oxidation of phenol over Fe-exchanged pillared beidellite. Water Research, 37(5), 1154-1160. http://dx.doi.org/10.1016/S0043-1354(02)00449-9

Cesaro, A., Naddeo, V., \& Belgiorno, V. (2013). Wastewater Treatment by Combination of Advanced Oxidation Processes and Conventional Biological Systems. Journal of Bioremediation \& Biodegradation, 4(8), 1-8. http://dx.doi.org/10.4172/2155-6199.1000208

Chatzisymeon, E., Diamadopoulos, E., \& Mantzavinos, D. (2009a). Effect of key operating parameters on the non-catalytic wet oxidation of olive mill wastewaters. Water Science and Technology, 59(12), 2509-2518. http://dx.doi.org/10.2166/wst.2009.321

Chatzisymeon, E., Xekoukoulotakis, N. P., Diamadopoulos, E., Katsaounis, A., \& Mantzavinos, D. (2009b). Boron-doped diamond anodic treatment of olive mill wastewaters: statistical analysis, kinetic modeling and biodegradability. Water Research, 43(16), 3999-4009. http://dx.doi.org/10.1016/j.watres.2009.04.007

Chatzisymeon, E., Xekoukoulotakis, N. P., \& Mantzavinos, D. (2009c). Determination of key operating conditions for the photocatalytic treatment of olive mill wastewaters. Catalysis Today, 144(1-2), 143-148. http://dx.doi.org/10.1016/j.cattod.2009.01.037

El-Gohary, F., Tawfik, A., Badawy, M., \& El-Khateeb, M. A. (2009). Potentials of anaerobic treatment for catalytically oxidized olive mill wastewater (OMW). Bioresource Technology, 100(7), 2147-2154. http://dx.doi.org/10.1016/j.biortech.2008.10.051

Fadil, K., Chahlaoui, A., Ouahbi, A, Zaid, A., \& Borja, R. (2003) Aerobic biodegradation and detoxification of wastewaters from the olive oil industry. International Biodeterioation \& Biodegradation, 51(1), 37-41. http://dx.doi.org/10.1016/S0964-8305(02)00073-2

Fajerwerg, K., Foussard, J., Perrard, A., \& Debellefontaine, H. (1997). Wet oxidation of phenol by hydrogen peroxide: The key role of $\mathrm{pH}$ on the catalytic behaviour of Fe-ZSM-5. Water Science and Technology, 35(4), 103-110. http://dx.doi.org/10.1016/S0273-1223(97)00015-2

Fernández-Bolaños, J. G., Rodríguez, G. G., Rodríguez, R. A., Guillén, R. B., \& Jiménez, A. A. (2006). Extraction of interesting organic compounds from olive oil waste. Grasas Y Aceites, 57(1), 95-106.

Garrido, H. S. E., Martinez, N. L., Camacho, R. F., \& Ramos, C. A. (2002). Kinetics of aerobic treatment of olive-mill wastewater (OMW) with Aspergillus terreus. Process Biochemistry, 37(10), 1169-1176. http://dx.doi.org/10.1016/S0032-9592(01)00332-6 
González-Rodríguez, J., Pérez-Juan, P., \& Luque de Castro, M. D. (2002). Method for the simultaneous determination of total polyphenol and anthocyan indexes in red wines using a flow injection approach. Talanta, 56(1), 53-59. http://dx.doi.org/10.1016/S0039-9140(01)00550-1

Gutteridge J. M. (1984). Reactivity of hydroxyl and hydroxyl-like radicals discriminated by release of thiobarbituric acid-reactive material from deoxy sugars, nucleosides and benzoate. Biochemical Journal, 224(3), 761-767.

Gutteridge, J. M., Rowley, D. A., \& Halliwell, B. (1981). Superoxide-dependent formation of hydroxyl radicals in the presence of iron salts. Detection of "free" iron in biological systems by using bleomycin-dependent degradation of DNA. Biochemical Journal, 199(1), 263-265.

Kiril Mert, B., Yonar, T., Yalili Kiliç, M., \& Kestioğlu, K. (2010). Pre-treatment studies on olive oil mill effluent using physicochemical, Fenton and Fenton-like oxidations processes. Journal of Hazardous Materials, 174(1-3), 122-128. http://dx.doi.org/10.1016/j.jhazmat.2009.09.025

Kosugi, H., Kato, T., \& Kikugawa, K. (1987). Formation of yellow, orange, and red pigments in the reaction of alk-2-enals with 2-thiobarbituric acid. Analytical Biochemistry, 165(2), 456-464. http://dx.doi.org/10.1016/0003-2697(87)90296-X

Lesage-Meesen, L., Navarro, D., Maunier, S., Sigoillot, J-C., Lorquin, J., Delattre, M., ... Labat, M. (2001). Simple phenolic content in olive residues as a function of extraction systems. Food Chemistry, 75(4), 501-507. http://dx.doi.org/10.1016/S0308-8146(01)00227-8

Malik, E. P., \& Singh, M. B. (1980). Plant Enzymology and Hittoenzymology (1st ed.), Kalyani Publishers: New Delhi, 286.

McNamara, C. J., Anastasiou, C. C., O'Flaherty, V., \& Mitchell, R. (2008). Bioremediation of olive mill

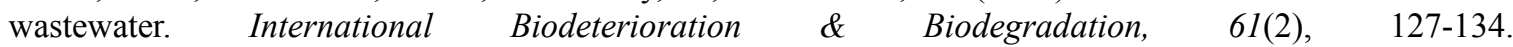
http://dx.doi.org/10.1016/j.ibiod.2007.11.003

Mekki, A., Dhouib, A., \& Sayadi, S. (2013). Review: Effects of olive mill wastewater application on soil properties and plants growth. Int J Recycl Org Waste Agric, 2(15), 1-7.

Neyens, E. \& Baeyens, J. (2003). A review of classic Fenton's peroxidation as an advanced oxidation technique. Journal of Hazardous Materials, 98(1-3), 33-50. http://dx.doi.org/10.1016/S0304-3894(02)00282-0

Niaounakis, M., \& Halvadakis, P. (2004). Olive-mill waste management: literature review and patent survey (1st ed.). Typothito-George Dardanos Publications, Athens.

Noradoun, C., Engelmann, M. D., McLaughlin, M., Hutcheson, R., Breen, K., Paszczynski, A., \& Cheng, I. F. (2003). Destruction of Chlorinated Phenols by Dioxygen Activation under Aqueous Room Temperature and Pressure Conditions. Ind. Eng. Chem. Res., 42(21), 5024-5030. http://dx.doi.org/10.1021/ie030076e

Poerschmann, J., Weiner, B., \& Baskyr, I. (2013). Organic compounds in olive mill wastewater and in solutions resulting from hydrothermal carbonization of the wastewater. Chemosphere, 92(11), 472-482. http://dx.doi.org/10.1016/j.chemosphere.2013.03.061

Oztekin, R., \& Sponza, D. T. (2013). Treatment of wastewaters from the olive mill industry by sonication. Journal of Chemical Technology \& Biotechnology, 88(2), 212-225. http://dx.doi.org/10.1002/jctb.3808

Rima, J., Aoun, E., Hanna, K., \& Li, Q. X. (2005). Degradation of phenol, into mineral compounds, in aqueous solutions using zero-valent iron powder (ZVIP). $J$ Phys IV, 124, 81-89. http://dx.doi.org/10.1051/jp4:2005124013

Rima, J., Qing, X. L., \& Aouezova, L. (2006). Generation of Free Radicals, analytical methods, Bacterial Disinfections, and Oxidative Destruction OF Organic Chemicals Using Zero Valent Iron and Other Metals. US Patent: WO 2006065825 A3

Rima, J., \& Assaker, K. (2012). Remediation of 4-nonylphenol in aqueous solution by using free radicals generated by the oxidative reactions. Environ. Sci. Pollut. Res. Int., 19(6), 2038-2043. http://dx.doi.org/10.1007/s11356-011-0690-2

Skerrat, G. A. (1999). The Application of Reedbed Treatment Technology to the Treatment of Effluents from Olive Oil Mills. Sfax, Tunisia; Staffordshire, UK.

Tekin, H., Bilkay, O., Ataberk, S. S., Balta, T. H., Ceribasi, H., Sanin F. D., ... Yetis, U. (2006). Use of Fenton oxidation to improve the biodegradability of a pharmaceutical wastewater. Journal of Hazardous Materials 
136(2), 258-265. http://dx.doi.org/10.1016/j.jhazmat.2005.12.012

Tezcan, Ün. Ü., Uğur, S., Koparal, A. S., \& Bakır Öğütveren, Ü. (2006). Electrocoagulation of olive mill

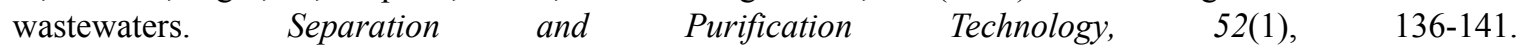
http://dx.doi.org/10.1016/j.seppur.2006.03.029

Ubay, G., \& Öztürk, I. (1997). Anaerobic treatment of olive mill effluents. Water Science and Technology, 36 (2-3), 287-294. http://dx.doi.org/10.1016/S0273-1223(97)00400-9

Zorpas, A. A., \& Inglezakis, V. J. (2011). Intergraded Applied Methodology for the Treatment of Heavy Polluted Waste waters from olive oil industries. Applied and Environmental Soil Science, 1-17. http://dx.doi.org/10.1155/2011/537814

\section{Copyrights}

Copyright for this article is retained by the author(s), with first publication rights granted to the journal.

This is an open-access article distributed under the terms and conditions of the Creative Commons Attribution license (http://creativecommons.org/licenses/by/3.0/). 